
A. Rhodes
P. Ferdinande
H. Flaatten
B. Guidet
P. G. Metnitz
R. P. Moreno

\title{
The variability of critical care bed numbers in Europe
}

Received: 9 March 2012

Accepted: 14 June 2012

Published online: 10 July 2012

(C) Copyright jointly held by Springer and ESICM 2012

Electronic supplementary material

The online version of this article (doi:10.1007/s00134-012-2627-8) contains supplementary material, which is available to authorized users.

\section{A. Rhodes $(\square)$}

Department of Intensive Care Medicine, St George's Healthcare NHS Trust and University of London,

London SW17 0QT, UK

e-mail: andyr@sgul.ac.uk; andrewrhodes@nhs.net

Tel.: +44-208-7255699

\section{P. Ferdinande}

Surgical and Transplantation ICU, University Hospital Gasthuisberg,

Leuven, Belgium

e-mail: patrick.ferdinande@uzleuven.be

H. Flaatten

ICU, Haukeland University Hospital, Bergen, Norway

e-mail: hans.flaatten@kir.uib.no

B. Guidet

Assistance Publique-Hôpitaux de Paris, Hôpital Saint-Antoine,

service de réanimation médicale,

Paris 75012, France

e-mail: bertrand.guidet@sat.aphp.fr
B. Guidet

Inserm, Unité de Recherche en

Épidémiologie Systèmes d'Information et Modélisation (U707), Paris 75012, France

\section{P. G. Metnitz}

Department of Anesthesia and General Intensive Care, AKH Wien, Medical University of Vienna, Vienna, Austria e-mail: philipp@metnitz.biz

\section{R. P. Moreno}

Unidade de Cuidados Intensivos Polivalente, Hospital de St. António dos Capuchos, Centro Hospitalar de Lisboa

Central, E.P.E., Lisbon, Portugal e-mail: r.moreno@mail.telepac.pt
Abstract Purpose: To quantify the numbers of critical care beds in Europe and to understand the differ- ences in these numbers between countries when corrected for popula- tion size and gross domestic product. Methods: Prospective data collec- tion of critical care bed numbers for each country in Europe from July 2010 to July 2011. Sources were identified in each country that could provide data on numbers of critical care beds (intensive care and inter- mediate care). These data were then cross-referenced with data from international databases describing population size and age, gross domestic product (GDP), expenditure

on healthcare and numbers of acute care beds. Results: We identified $2,068,892$ acute care beds and 73,585 (2.8\%) critical care beds. Due to the heterogeneous descriptions of these beds in the individual countries it was not possible to discriminate between intensive care and intermediate care in most cases. On average there were 11.5 critical care beds per 100,000 head of population, with marked differences between countries (Germany 29.2, Portugal 4.2). The numbers of critical care beds per country corrected for population size were positively correlated with GDP $\left(r^{2}=0.16, p=0.05\right)$, numbers of acute care beds corrected for population $\left(r^{2}=0.12, p=0.05\right)$ and the percentage of acute care beds designated as critical care $\left(r^{2}=0.59\right.$, $p<0.0001)$. They were not correlated with the proportion of GDP expended on healthcare. Conclusions: Critical care bed numbers vary considerably between countries in Europe. Better understanding of these numbers should facilitate improved planning for critical care capacity and utilization in the future.

Keywords Intensive care . Bed numbers - Demand - Supply 


\section{Introduction}

The need for critical care capacity worldwide is increasing [1]. This has been described in the USA, where it is recognized that future provision of critical care is unlikely to be able to meet the estimated demands [2]. This potential shortfall has also been described in other countries, such as Norway, as a result of changes in population demographics [3]. Similar patterns are being described in many other countries, although most have been unable to accurately quantify the problem. The future increase in demand is due to a number of factors that include significant changes in the size and age of the population, together with increasing prevalence of relevant comorbidities and changing perceptions as to what critical care can offer $[4,5]$.

The identification of mechanisms to prevent this mismatch developing needs to take place with some urgency. Several factors have to be taken into account, all of which interact with each other at a variety of levels. Unless admission and referral practices change, the increased future demand can only be met by an increase in total capacity $[2,6]$. Without an increase in capacity there will need to be rationing or triaging of available resource to ensure that patients who are most likely to benefit can receive the care they need [7]. Although part of this change may be met by increased provision of outreach and intermediate care [8], there will also need to be an increase in the number of critical care beds and hence also an increase in the numbers of appropriately skilled healthcare professionals to care for the increased number of patients.

To plan for these changes there is a need to better understand the current situation of critical care bed availability [4, 9-11]. Although several countries publish the numbers of beds provided, little is known about how this varies between countries even within a confined geographical region such as Europe. This study therefore aims to identify the total numbers of critical care beds for each country in Europe and to adjust the bed numbers to the population in order to illustrate the differences in resource provided for this group of patients.

\section{Materials and methods}

This was an observational study assessing the numbers of adult critical care beds in each country in Europe between July 2010 and July 2011. For the purposes of this study critical care includes intensive care (ICU) and intermediate care beds (IMCU). To be included in this study, the bed had to be open, staffed and fulfil any relevant national criteria, where available. The following were excluded from the data collection: private healthcare providers, neonatal and paediatric intensive care beds, coronary care, stroke and pure renal units. The numbers of beds in each country were obtained by assessing data from reliable governmental sources (websites and contacts), national societies with a declared interest in intensive care medicine, national training boards, faculties or colleges and national registries where appropriate. Data obtained were then cross-referenced with the national council representative for the European Society of Intensive Care Medicine (ESICM) and other personal contacts with knowledge of their country, in order to provide face validity for the numbers obtained. In countries where, following this approach, data were still not forthcoming, personal contacts were used and numbers were estimated according to a local sample assessment.

Data describing the total population of each country were identified from a series of publicly available databases. These included the European Commission database (Eurostat) (ec.europa.eu/Eurostat), the World Health Organization (WHO) regional office for Europe, the Central Intelligence Agency (CIA) World Factbook (https://www.cia.gov/library/publications/the-world-factbook/) and the Organisation for Economic Co-operation and Development (OECD). Data were analysed using Graphpad Prism (version 5.1a) and are presented as numbers with a percentage. Linear regression analysis was performed in order to assess likely associations. A $p$ value of less than 0.05 was taken to be significant.

\section{Results}

In many countries, readily accessible data with regards to the provision of critical care bed numbers were not available. In some countries, for instance the UK, there were governmental census data. In other countries, data were available through national societies (for instance, Germany). In others no data were found, and local clinicians had to count the beds themselves (Portugal). There were marked differences in how critical care services were set up between countries, with some having separate intermediate and intensive care (Table ESM 1), whilst others manage both flexibly within single services. Some countries also included higher levels of care in acute general wards, for instance the Czech Republic.

We identified a total of 2,068,892 acute care hospital beds in Europe, with marked differences in total numbers of beds and also in the numbers of beds corrected per 100,000 of population between countries (Table 1). On average there were 409 acute care beds per 100,000 head of population. A total of 73,585 critical care beds were identified in Europe. This equates to an average of 11.5 beds per 100,000 head of population for Europe as a whole. The country with the highest number of beds was Germany $(23,890)$, and the country with the least number of beds was Andorra (6). When the total numbers of beds 
Table 1 Descriptors of population size, economic strength and health expenditure in European countries

\begin{tabular}{|c|c|c|c|c|c|}
\hline & $\begin{array}{l}\text { Total size of } \\
\text { population }\end{array}$ & $\begin{array}{l}\text { Gross domestic } \\
\text { product (GDP) } \\
(\$ \text { millions) }\end{array}$ & $\begin{array}{l}\text { Gross domestic } \\
\text { product }(\mathrm{GDP}) \\
\text { per inhabitant }(\$)^{\mathrm{b}}\end{array}$ & $\begin{array}{l}\text { Total expenditure } \\
\text { on health as a } \\
\% \text { of GDP }\end{array}$ & $\begin{array}{l}\% \text { of population } \\
\text { over } 65 \text { years } \\
\text { of age }\end{array}$ \\
\hline Andorra & 84,082 & 2,893 & 34,407 & 7.7 & 13.0 \\
\hline Austria & $8,404,252$ & 377,382 & 44,904 & 8.6 & 18.2 \\
\hline Belgium & $11,007,020$ & 467,779 & 42,498 & 8.2 & 18.0 \\
\hline Bulgaria & $7,504,868$ & 47,702 & 6,356 & 4.4 & 18.2 \\
\hline Croatia & $4,425,747$ & 60,834 & 13,745 & 7.8 & 16.9 \\
\hline Cyprus & 804,435 & 23,174 & 28,808 & 6.0 & 10.4 \\
\hline Czech Republic & $10,532,770$ & 192,030 & 18,232 & 6.9 & 16.3 \\
\hline Denmark & $5,560,628$ & 309,866 & 55,725 & 9.8 & 17.1 \\
\hline Estonia & $1,340,194$ & 19,253 & 14,366 & 5.3 & 17.7 \\
\hline Finland & $5,375,276$ & 239,177 & 44,496 & 6.8 & 17.8 \\
\hline France & $65,075,310$ & $2,562,742$ & 39,381 & 9.2 & 16.8 \\
\hline Germany & $81,748,892$ & $3,286,451$ & 40,202 & 8.9 & 20.6 \\
\hline Greece & $11,329,618$ & 305,415 & 26,957 & 5.8 & 19.6 \\
\hline Hungary & $9,986,000$ & 130,421 & 13,060 & 5.2 & 16.9 \\
\hline Iceland & 318,452 & 12,594 & 39,548 & 7.9 & 12.7 \\
\hline Ireland & $4,480,176$ & 206,985 & 46,200 & 7.2 & 11.6 \\
\hline Italy & $60,626,508$ & $2,055,114$ & 33,898 & 7.4 & 20.3 \\
\hline Latvia & $2,229,641$ & 24,013 & 10,770 & 8.1 & 16.9 \\
\hline Lithuania & $3,244,601$ & 36,370 & 11,209 & 7.8 & 16.5 \\
\hline Luxembourg & 511,840 & 54,950 & 107,358 & 4.1 & 14.9 \\
\hline The Netherlands & $16,654,979$ & 780,668 & 46,873 & 5.5 & 15.6 \\
\hline Norway & $4,920,305$ & 412,990 & 83,936 & 8.1 & 16.0 \\
\hline Poland & $38,200,037$ & 469,401 & 12,288 & 5.3 & 13.7 \\
\hline Portugal & $10,636,979$ & 229,154 & 21,543 & 5.7 & 18.0 \\
\hline Romania & $21,413,815$ & 161,629 & 7,548 & 5.4 & 14.8 \\
\hline Slovakia & $5,435,273$ & 87,450 & 16,089 & 6.0 & 12.8 \\
\hline Slovenia & $2,050,189$ & 47,733 & 23,282 & 6.8 & 16.8 \\
\hline Spain & $46,152,926$ & $1,409,946$ & 30,549 & 7.0 & 17.1 \\
\hline Sweden & $9,415,570$ & 458,725 & 48,720 & 8.2 & 19.7 \\
\hline Switzerland & $7,866,500$ & 527920 & 67,110 & 6.8 & 17.0 \\
\hline UK & $62,435,709$ & $2,250,209$ & 36,040 & 8.2 & 16.5 \\
\hline
\end{tabular}

${ }^{a}$ CIA World Factbook

b Eurostat 2011

c OECD $2009 \%$ GDP

per country were corrected for the size of the population, the differences were less marked although still present (Table 2). Germany still remained the country with the highest number of beds $(29.2 / 100,000)$, whereas Portugal had the lowest $(4.2 / 100,000)$ (Fig. 1).

The total numbers of critical care beds per country corrected for population size were positively correlated to population size $\left(r^{2}=0.69, p<0.0001\right)$ but only weakly related to the country's gross domestic product (GDP) (in millions of US dollars) $\left(r^{2}=0.16, p=0.05\right)$, the proportion of GDP expended on healthcare $\left(r^{2}<0.0001\right.$, $p=0.91$ ) (Fig. 2) or the proportion of elderly patients in the population $\left(r^{2}=0.04, p=0.31\right)$.

On average there are 2.8 critical care beds for every 100 acute care beds across Europe. This again hides a marked variation, however, with Germany and Luxembourg having the highest percentage at 5.1/100,000 and the Czech Republic the lowest $(1.3 / 100,000)$ (Table 2). The numbers of critical care beds were correlated with the numbers of acute care beds corrected for population size $\left(r^{2}=0.12, p=0.05\right)($ Fig. 3$)$ and also the percentage of acute care beds as compared with critical care $\left(r^{2}=0.59\right.$, $p<0.0001$ ) (Figure ESM 1).

\section{Discussion}

In this work we found marked heterogeneity in the numbers of critical care beds between European countries, even when corrected for population size and age distribution, gross domestic product, expenditure on healthcare and numbers of total acute care beds. The differences in provision can be exemplified by the fact the Germany has 6.9 times the number of intensive care beds compared with Portugal per head of population.

The artificial split of critical care beds into either intermediate or intensive care varies widely across Europe despite the move to standardize descriptions across the region [12, 13]. This lack of a consistent definition reduces our ability to compare clinical practice and organizational models across borders and therefore will 
Table 2 Data describing numbers of adult acute care, intermediate care and intensive care beds per European country

\begin{tabular}{|c|c|c|c|c|c|c|c|c|}
\hline & $\begin{array}{l}\text { Acute care } \\
\text { beds }^{\mathrm{a}}\end{array}$ & $\begin{array}{l}\text { Acute } \\
\text { care beds/ } \\
100,000 \\
\text { population }\end{array}$ & $\begin{array}{l}\text { Intermediate } \\
\text { care (IMCU) } \\
\text { beds }\end{array}$ & $\begin{array}{l}\text { Intensive } \\
\text { care (ICU) } \\
\text { beds }\end{array}$ & $\begin{array}{l}\text { Critical } \\
\text { care } \\
\text { beds }\end{array}$ & $\begin{array}{l}\text { ICU and } \\
\text { IMCU beds/ } \\
100,000 \\
\text { population }\end{array}$ & $\begin{array}{l}\text { ICU beds } \\
\text { as \% of } \\
\text { acute care } \\
\text { beds }\end{array}$ & $\begin{array}{l}\text { GDP } \\
\text { (\$million)/ } \\
\text { ICU beds }\end{array}$ \\
\hline Andorra & 188 & 224 & & & 6 & 7.1 & 3.2 & 482.2 \\
\hline Austria & 48,446 & 635 & 569 & 1,264 & 1,833 & 21.8 & 3.4 & 205.9 \\
\hline Belgium & 50,156 & 456 & & & 1,755 & 15.9 & 3.5 & 266.5 \\
\hline Bulgaria & 57,460 & 766 & & & 913 & 12.2 & 1.6 & 52.2 \\
\hline Croatia & 15,629 & 353 & & & 650 & 14.7 & 4.2 & 93.6 \\
\hline Cyprus & 2,813 & 350 & 9 & 83 & 92 & 11.4 & 3.3 & 251.9 \\
\hline Czech Republic & 91,068 & 865 & & & 1,227 & 11.6 & 1.3 & 156.5 \\
\hline Denmark & 17,124 & 308 & & & 372 & 6.7 & 2.2 & 833.0 \\
\hline Estonia & 5,096 & 380 & 72 & 124 & 196 & 14.6 & 3.8 & 98.2 \\
\hline Finland & 12,442 & 231 & 28 & 301 & 329 & 6.1 & 2.6 & 727.0 \\
\hline France & 232,821 & 358 & 3,471 & 4,069 & 7,540 & 11.6 & 3.2 & 339.9 \\
\hline Germany & 469,791 & 575 & & & 23,890 & 29.2 & 5.1 & 137.6 \\
\hline Greece & 44,411 & 392 & 30 & 650 & 680 & 6.0 & 1.5 & 449.1 \\
\hline Hungary & 41,574 & 416 & & & 1,374 & 13.8 & 3.3 & 94.9 \\
\hline Iceland & 1,169 & 367 & & & 29 & 9.1 & 2.5 & 434.3 \\
\hline Ireland & 12,202 & 272 & 88 & 201 & 289 & 6.5 & 2.4 & 716.2 \\
\hline Italy & 201,932 & 333 & & & 7,550 & 12.5 & 3.7 & 272.2 \\
\hline Latvia & 11,833 & 531 & & & 217 & 9.7 & 1.8 & 110.7 \\
\hline Lithuania & 17,061 & 526 & & & 502 & 15.5 & 2.9 & 72.5 \\
\hline Luxembourg & 2,511 & 204 & 27 & 100 & 127 & 24.8 & 5.1 & 432.7 \\
\hline The Netherlands & 56,085 & 337 & & & 1,065 & 6.4 & 1.9 & 733.0 \\
\hline Norway & 13,639 & 277 & & & 395 & 8.0 & 2.9 & $1,045.5$ \\
\hline Poland & 156,662 & 410 & & & 2,635 & 6.9 & 1.7 & 178.1 \\
\hline Portugal & 31,722 & 298 & & 451 & 451 & 4.2 & 1.4 & 508.1 \\
\hline Romania & 108,611 & 507 & 2,574 & 2,000 & 4,574 & 21.4 & 4.2 & 35.3 \\
\hline Slovakia & 32,560 & 599 & & & 500 & 9.2 & 1.5 & 174.9 \\
\hline Slovenia & 7,656 & 373 & & & 131 & 6.4 & 1.7 & 364.4 \\
\hline Spain & 124,194 & 269 & & & 4,479 & 9.7 & 3.6 & 314.8 \\
\hline Sweden & 26,131 & 278 & & & 550 & 5.8 & 2.1 & 834.0 \\
\hline Switzerland & 28,096 & 357 & & & 866 & 11.0 & 3.1 & 609.6 \\
\hline UK & 147,809 & 237 & 1,737 & 2,377 & 4,114 & 6.6 & 2.8 & 547.0 \\
\hline
\end{tabular}

${ }^{\text {a }}$ World Health Organization Regional Office for Europe (2009)

not help individual countries to build the case for additional capacity in future years. We believe that it would be beneficial to have a European standard definition of exactly what an intensive care bed is, which could then be implemented within the different countries. This definition could include factors related to the unit's ability to address organ dysfunction/failure, availability of beds throughout the day and week, patient/nurse and patient/ doctor ratios, severity of illness and the operative rather than the planned mean level of care of the ICU [14].

The overall number of critical care beds for Europe was $11.5 / 100,000$ head of population. This is in marked contrast to the number for the USA, which Carr found to be $28 / 100,000$ in 2010 [15]. The heterogeneity of the data between European countries is consistent with the findings reported by other groups. Wunsch and colleagues [9] presented similar data although only on a very limited number (six) of European countries in addition to a number of other non-European countries. The provision of intensive care beds that they found within the European region was very similar to the numbers presented in this study, despite their collection of data being from 2005, 5 years earlier.

An interesting question that arises from examination of this data is how the different countries cope with the widely differing levels of critical care capacity. Presumably, in a grossly homogeneous geographical and developed region such as Europe, one would expect that comparable numbers of patients would develop acute critical illness in the different countries. One would hence expect that the different levels of provision should have a major impact on practice and hence presumably outcomes [6, 16-19]. Again comparing Portugal and Germany, it is impossible that Portugal is able to admit the same amount of patients to critical care as in Germany. The implication must therefore be that either patients in Portugal with need for critical care are unable to get it or that Germany overprovides intensive care for its population. Only further analysis of data that describe provision and practice of critical care in detail across countries will enable us to answer these questions. As a start, comparison of data 


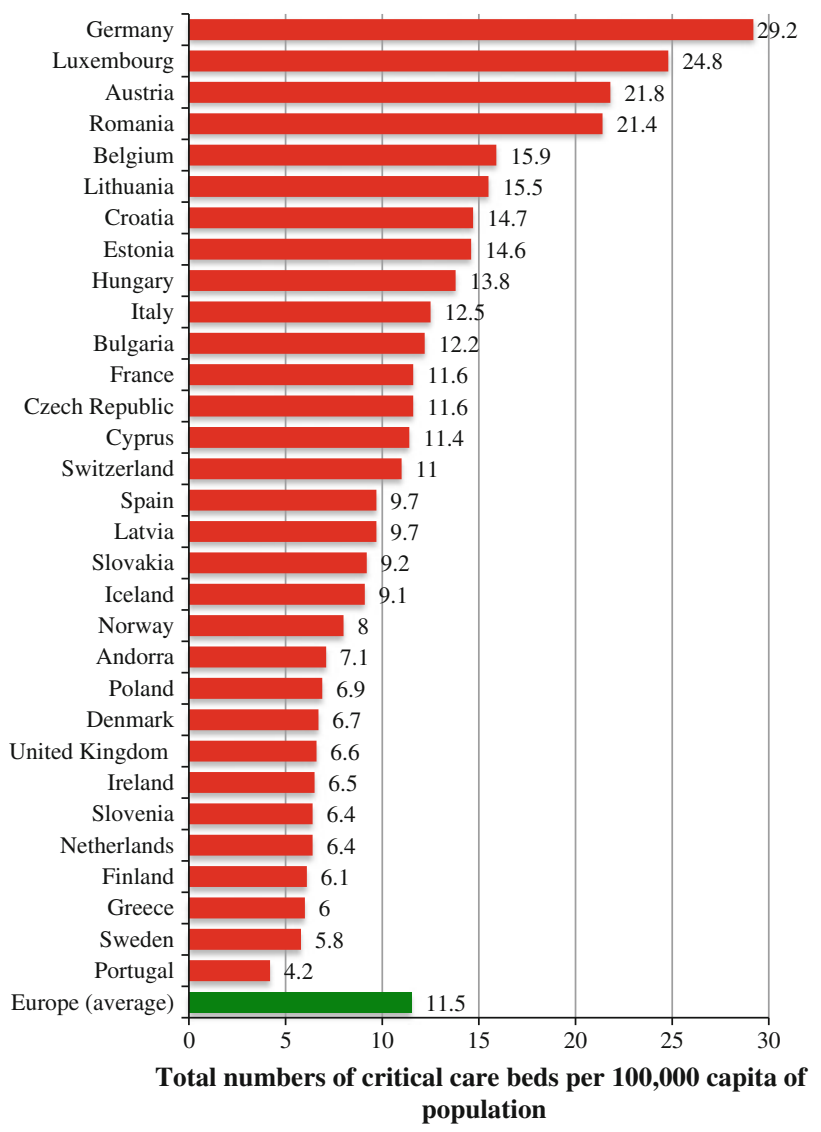

Fig. 1 Numbers of critical care beds corrected for size of population (per 100,000 inhabitants) for European countries from European countries with established national registries of intensive care could give more insight into such details. At present such registries are operative in England, Scotland, Norway, Finland and Sweden, The Netherlands, and Austria. With the exception of Austria, these are all countries with a relatively low number of ICU beds per population unit, as can be seen in Fig. 1.

We have been able to demonstrate that there are still major differences within Europe regarding provision of critical care services. These differences are too large to be explained purely by differences in the characteristics of the populations and are inadequately explained by the economic strength of the country. In that respect, the three wealthiest countries in Europe [measured in GDP (\$)/ inhabitant]: Luxembourg $(107,358)$, Norway $(83,936)$, and Switzerland $(67,110)$ have respectively 21,8 , and 11 ICU beds/100,000 population. It seems likely that the healthcare models present in each country have a major impact on the development and prioritization of this resource. This is likely to reflect a variety of factors that range from specialty status, bed and patient models and bed utilization (admission and discharge criteria) protocols. In addition, the staffing of other hospital wards may also play a major role. We restricted this study to the provision of beds through the public healthcare systems, excluding private providers. There may, therefore, be an underestimation of numbers in some countries due to the missing private sector.

More research is urgently needed to understand how the differing numbers of critical care beds impact on
Fig. 2 Comparison of the numbers of critical care beds per 100,000 against the proportion of health expenditure as a percentage of gross domestic product (in millions of US dollars). Lines represent linear regression analysis together with $95 \%$ confidence intervals around the line $\left(r^{2}<0.0001, p=0.91\right)$

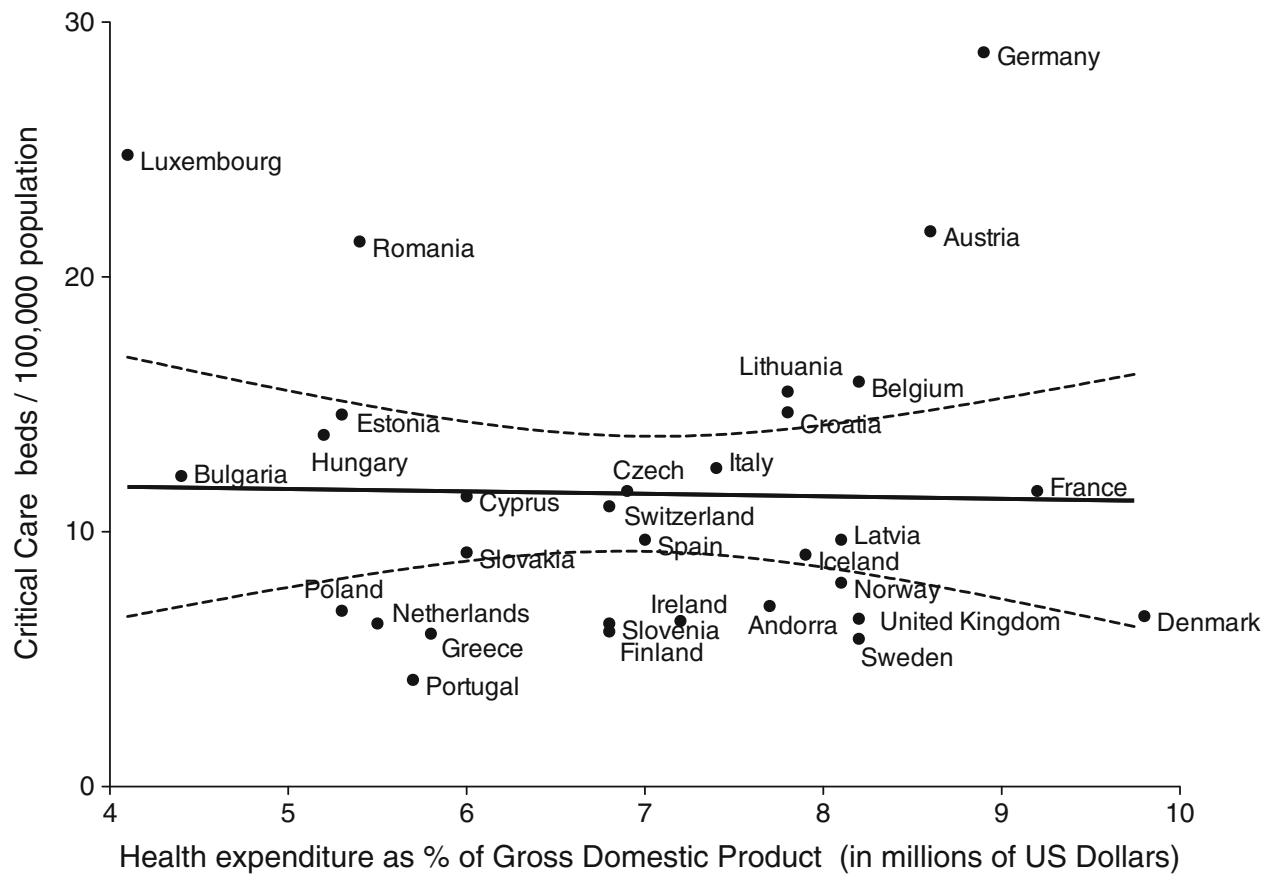


Fig. 3 Linear regression analysis of the numbers of critical care beds corrected per 100,000 population against the numbers of acute care of beds corrected for population size. Data presented are the regression line together with the around it $\left(r^{2}=0.13, p=0.05\right)$ $95 \%$ confidence intervals

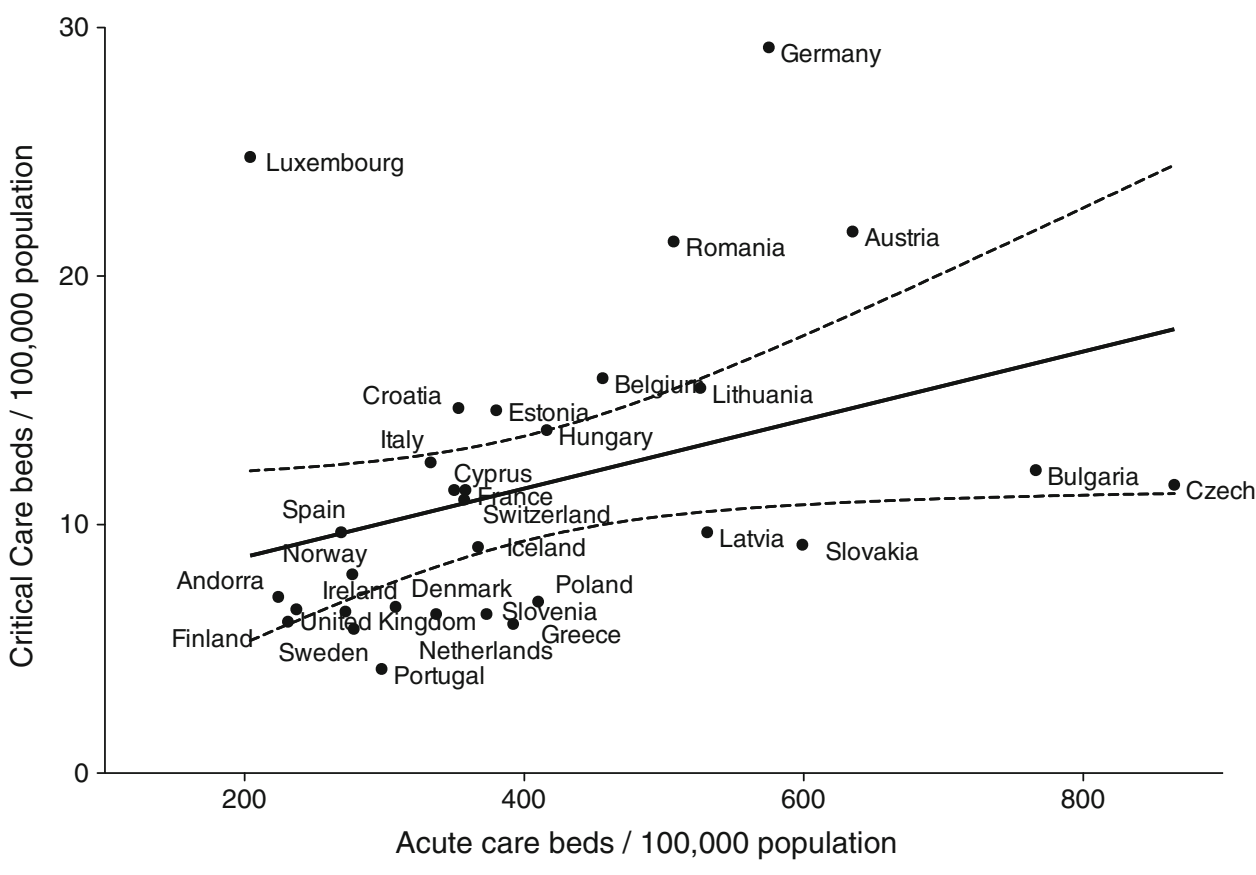

practice and ultimately on patient outcomes. If the need for these beds continues to grow, then the most effective and cost-efficient use of this level of care must be developed in order for most countries to be able to afford this level of provision of healthcare.

Acknowledgments ESICM: Claudia Arena and Giulia Evolvi, Andorra: Antoni Margarit, Austria: Philipp Metnitz, Austrian Center of Documentation and Quality Assurance in Intensive Care Medicine (ASDI), Belgium: Federal Government. Patrick Ferdinande and Eric Hoste, Bulgaria: National Center of Health Informatics-Public Health Statistics, Croatia: Ino Husedzinovich, president of the Croatian Society of Intensive Care Medicine, Czech Republic: Ivan Novak, scientific secretary of the Czech Society of Anesthesia and Intensive Care Medicine, Cyprus Department of Medical and Public Health Service-Maria Psalti and Theodorus Kyprianou, Denmark: National Board of Health, Estonia: Indrek Rätsep, from the database of the Estonian Society of Anaesthesiologists, Finland: Ville Pettila-Finnish Society of Intensive Care Medicine, France: Agence technique de l'information hospitalière (ATIH), Germany: German Association of Anaesthesiology and Intensive Care, Greece: Apostolos Armaganidis, president of the Greek Society of Intensive Care Medicine,
Hungary: Akos Csomos for the Hungary national health fund database, Iceland: Kari Hreinsson, president of the Icelandic Society of Anesthesiology and Intensive Care Medicine, Ireland: Patrick Seigne, The Prospectus Report (A Review of Adult Critical Care Services in Ireland, 2009), Italy: Ministry of Health, Latvia: Indulis Vagas (president of the National Society of Anesthesiology and Reanimation of Latvia), Lithuania: Jurate Sypilaite-Lithuanian Society of Intensive Care Medicine, Luxembourg: Max Martin, Malta: Carmel Abela, The Netherlands: Jozef Kesecioglu and Hans van der Spoel, Norway: Hans Flaatten, Poland: Krystof KuszaPolish Ministry of Health, Portugal: Rui Moreno; Colégio de Medicina Intensiva da Ordem dos Médicos; Sociedade Portuguesa de Medicina Intensiva, Romania: National Center for Statistic of the Ministry of Health-Ioana Grigoras and Natalia Hagau, Slovakia: Jozef Firment Slovakian Society of Intensive Care Medicine, Slovenia: Slovenian Health Statistic Yearbook, Spain: Cristobal Leon Gil and the SEMICYUC and Cesar Aldecoa, Sweden: Goran Karlstrom, Switzerland: Hans Rothen, National coordinator, data from the Swiss Society of Intensive Care Medicine, UK: Department of Health (2010), Scottish Intensive Care Society, Linda Mulholland, Critical Care Networks of Wales and Northern Ireland.

Conflicts of interest None.

\section{References}

1. Rhodes A, Chiche J-D, Moreno R (2011) Improving the quality of training programs in intensive care: a view from the ESICM. Intensive Care Med $37: 377-379$
2. Angus DC, Kelley MA, Schmitz RJ, White A, Popovich J, for the Committee on Manpower for Pulmonary and Critical Care Societies (COMPACCS) (2000) Current and projected workforce requirements for care of the critically ill and patients with pulmonary disease: can we meet the requirements of an aging population? JAMA $284: 2762-2770$
3. Laake JH, Dybwik K, Flaatten HK, Fonneland I-L, Kvåle R, Strand K (2010) Impact of the post-World War II generation on intensive care needs in Norway. Acta Anaesthesiol Scand $54: 479-484$ 
4. Adhikari NK, Fowler RA, Bhagwanjee S, Rubenfeld GD (2010) Critical care and the global burden of critical illness in adults. Lancet 376:1339-1346

5. Piers RD, Azoulay E, Ricou B, Dekeyser Ganz F, Decruyenaere J, Max A, Michalsen A, Maia PA, Owczuk R, Rubulotta F, Depuydt P, Meert AP, Reyners AK, Aquilina A, Bekaert M, Van den Noortgate NJ, Schrauwen WJ, Benoit DD (2011) Perceptions of appropriateness of care among European and Israeli intensive care unit nurses and physicians. JAMA 306:2694-2703

6. Wunsch H, Angus DC, Harrison DA, Linde-Zwirble WT, Rowan KM (2011) Comparison of medical admissions to intensive care units in the United States and United Kingdom. Am J Respir Crit Care Med 183:1666-1673

7. Eastman N, Philips B, Rhodes A (2010) Triaging for adult critical care in the event of overwhelming need. Intensive Care Med 36:1076-1082

8. Hillman K, Chen J, Cretikos M, Bellomo R, Brown D, Doig G, Finfer S, Flabouris A, Merit Study Investigators (2005) Introduction of the medical emergency team (MET) system: a cluster-randomised controlled trial. Lancet 365:2091-2097
9. Wunsch H, Angus DC, Harrison DA, Collange O, Fowler R, Hoste EAJ, de Keizer NF, Kersten A, Linde-Zwirble WT, Sandiumenge A, Rowan KM (2008) Variation in critical care services across North America and Western Europe. Crit Care Med 36(2787-2793):e2781-e2789

10. Adhikari NKJ, Rubenfeld GD (2011) Worldwide demand for critical care. Curr Opin Crit Care 17:620-625

11. Murthy S, Wunsch H (2012) Clinical review: International comparisons in critical care-lessons learned. Crit Care 16:218

12. Rhodes A, Moreno RP, Chiche J-D (2011) ICU structures and organization: putting together all the pieces of a very complex puzzle. Intensive Care Med 37:1569-1571

13. Valentin A, Ferdinande P, ESICM Working Group on Quality Improvement (2011) Recommendations on basic requirements for intensive care units: structural and organizational aspects. Intensive Care Med 37:1575-1587

14. Moreno R, Reis Miranda D (1998) Nursing staff in intensive care in Europe: the mismatch between planning and practice. Chest 113:752-758
15. Carr BG, Addyson DK, Kahn JM (2010) Variation in critical care beds per capita in the United States: implications for pandemic and disaster planning. JAMA, J Am Med Assoc 303:1371-1372

16. Wunsch H, Linde-Zwirble WT, Harrison DA, Barnato AE, Rowan KM, Angus DC (2009) Use of intensive care services during terminal hospitalizations in England and the United States. Am J Respir Crit Care Med 180:875-880

17. Rapoport J, Teres D, Barnett R, Jacobs P, Shustack A, Lemeshow S, Norris C, Hamilton S (1995) A comparison of intensive care unit utilization in Alberta and western Massachusetts. Crit Care Med 23:1336-1346

18. Sirio CA, Tajimi K, Taenaka N, Ujike Y, Okamoto K, Katsuya H (2002) A cross-cultural comparison of critical care delivery: Japan and the United States. Chest 121:539-548

19. Zimmerman JE, Knaus WA, Judson JA, Havill JH, Trubuhovich RV, Draper EA, Wagner DP (1988) Patient selection for intensive care: a comparison of New Zealand and United States hospitals. Crit Care Med 16:318-326 